\title{
Electrocoagulation Process in the Context of Disinfection Mechanism
}

\author{
Djamel Ghernaout ${ }^{1,2 *}$, Noureddine Elboughdiri ${ }^{1,3}$ \\ ${ }^{1}$ Chemical Engineering Department, College of Engineering, University of Ha'il, Ha'il, Saudi Arabia \\ ${ }^{2}$ Chemical Engineering Department, Faculty of Engineering, University of Blida, Blida, Algeria \\ ${ }^{3}$ Departement de Genie Chimique de Procedes, Laboratoire Modelisation, Analyse, et Commande des Systemes, Ecole Nationale \\ d'Ingenieurs de Gabes (ENIG), Rue Omar Ibn-Elkhattab, Gabes, Tunisia \\ Email: ^djamel_andalus@hotmail.com
}

How to cite this paper: Ghernaout, D. and Elboughdiri, N. (2020) Electrocoagulation Process in the Context of Disinfection Mechanism. Open Access Library Journal, 7: e6083.

https://doi.org/10.4236/oalib.1106083

Received: January 16, 2020

Accepted: February 7, 2020

Published: February 10, 2020

Copyright $\odot 2020$ by author(s) and Open Access Library Inc.

This work is licensed under the Creative Commons Attribution International License (CC BY 4.0).

http://creativecommons.org/licenses/by/4.0/

\section{(c) (i) Open Access}

\begin{abstract}
During the last three decades, the electrocoagulation (EC) process has known an exemplary renaissance in the field of water and wastewater treatment. Several researchers focused on applying this electrochemical technology in removing diverse pollutants such as pathogens. During EC method, the coagulant is furnished via solubilizing sacrificial electrodes upon an applied electric field. The easiness of the technology and the side phenomena involving the generation of gas bubbles are the major advantages. This work discusses briefly the main achievements and mechanisms in employing EC in disinfecting water. In the EC process, the microbes may be demobilized thanks to the direct adsorption on the surface of the anode pursued by electron transfer, and physical elimination through floating pathogens with formed hydrogen gas and/or precipitating with the produced flocs. Integrating EC with free radical assisted processes (e.g., electrooxidation), magnetic field and/or ultrasonic field remains an encouraging method to promote its implantation at full scale. Membrane processes should be considered as safe barriers towards disinfection by-products and hydroxyl radicals.
\end{abstract}

\section{Subject Areas \\ Environmental Sciences}

\section{Keywords}

Electrocoagulation (EC), Electrochemical Disinfection, Disinfection

Mechanism, Wastewater Treatment, Organic Matter, Escherichia coli

\section{Introduction}

During the last decades, there is no doubt that water and wastewater treatment 
industry has known a marked advance [1] [2]. However, water contamination has likewise greatly augmented due to the uncontrolled industrial expansions [3] [4] [5]. As a result, the at hand water resources became contaminated with a large range of contaminants generating various health issues [6] [7]. Some of such contaminants, the pathogenic and non-pathogenic microorganisms are categorized at the most elevated danger than remaining contaminants because of the towering cases of illness and death that they could provoke [8] [9] [10] [11]. For example, it has been mentioned that the pathogens trigger diverse waterborne diseases, like diarrhea and gastrointestinal, which successively lead to around 2,000,000 deaths/year [8] [12]. Thus, several disinfection techniques, like chlorination [13] [14] [15] [16], ozonation, and irradiation with ultraviolet, have been employed to kill pathogenic and non-pathogenic microorganisms from water [17]-[24]. As an illustration, chlorination process has been largely employed in the course of the 1970s as an efficacious and low-cost disinfection technique. During this chemical method, the strong oxidizing capacity of chlorine destructs the fundamental enzymes of microbes, which conducts to killing such biological contaminants [25] [26]. The primary drawback of chlorination process remains the formation of very poisonous disinfection by-products (DBPs). For example, the reaction among the chlorine and natural organic matter (such as humic substances [27]-[32]) forms trihalomethanes, which are famous as carcinogenic chemicals [25] [26]. Membrane processes, such as microfiltration and ultrafiltration techniques, are additionally efficient barriers for eliminating microbes; nevertheless, their implementing is considerably restricted via the fouling issues and the elevated operational cost [1]. Ozonation is different method that has been utilized as a disinfection technology; indeed, it has been noted that the ozone is a strong oxidant that can demobilize the microbes via breaking down their cell membrane [25] [33]. Even if the ozonation method is very efficacious and it does not form trihalomethanes like chlorination, it remains costly as contrasted to various conventional techniques [34]; further, it has been established that it may provoke the production of N-nitrosodimethylamine [33].

Lately, the disinfection engineering has known outstanding progress through merging several technique or via employing novel composite materials. For instance, researchers [35] suggested a fresh disinfection process that employs a tubular coaxial-electrode copper ionization cell to disinfect drinking water. The acquired findings depicted that this technique eliminated 6-log of Escherichia coli during 2 min of application at running voltage of $1.5 \mathrm{~V}$. Scientists [36] employed advanced electrochemical cell that was furnished with boron doped diamond electrodes to disinfect seawater. The results of this investigation proved that this advanced electrochemical cell reduces 4.8 -Log of natural marine heterotrophic bacteria at energy consumption of $0.264 \mathrm{kWh} / \mathrm{m}^{3}$. The same researchers [36] implements the nanotechnology [37] to present a disinfection technology that comprise an anodic multiwall carbon nanotube filter to kill viruses and $E$. coli in water. They discovered that such technique diminished the number of viruses and $E$. coli, during $30 \mathrm{~s}$ at voltage of $3 \mathrm{~V}$, to below detection limit [1]. 
Electrocoagulation (EC) process has lately received a big deal of focus as an efficient technology to eliminate microbes from wastewater and water thanks to its simplicity, selectivity, and comparatively low operating cost [38]-[44]. Further, the EC technique does not require chemicals injections to elevate the treatment performance (except for the case where the ionic strength is weak so supporting electrolyte should be added to increase the solution electric conductivity [45]), and it may be with ease automated and combined with additional treatment setups [46] [47] [48]. In addition, EC technology hugely decreases the volume of the formed solid waste (sludge) that needs elevated treatment cost [49] [50]; which successively greatly reduces the working price of the EC technique [51] [52]. These merits of the EC process place it extremely encouraging choice to the classical treatment techniques [53] [54] [55]. On the other hand, absence of reactor design (simple horizontal or vertical arrangement of square or rectangular plate electrodes inside a container) and the care of the EC to the chemical composition of the liquid being handled constitute the major obstacles of the EC technology [1] [51] [56] [57] [58].

\section{Electrocoagulation Process in Terms of Disinfection Pathways}

The literature presents numerous explications for the routes of killing microorganisms via electrochemical technologies, which could be listed in Table 1 [19] [59] [60] [61].

In the EC process, in addition to the aforesaid routes, the microbes may be demobilized thanks to the direct adsorption on the surface of the anode pursued by electron transfer, and physical elimination through floating pathogens with formed hydrogen gas and/or precipitating with the produced flocs [34] [59] [60]. Table 2 presents the detailed EC reactions in the case of Fe [62] and Al electrodes.

More importantly, so powerful oxidizing agents, like $\mathrm{HOCl}, \mathrm{OCl}^{-}, \mathrm{ClO}_{2}$ and $\mathrm{Cl}_{2}$, are formed throughout the EC technology following the next reactions [59] [67]:

$$
\begin{gathered}
2 \mathrm{Cl}^{-} \rightarrow \mathrm{Cl}_{2}+2 \mathrm{e}^{-} \\
\mathrm{Cl}_{2}+2 \mathrm{OH}^{-} \rightarrow \mathrm{H}_{2} \mathrm{O}+\mathrm{OCl}^{-}+\mathrm{Cl}^{-} \\
\mathrm{Cl}_{2}+4 \mathrm{H}_{2} \mathrm{O} \rightarrow 2 \mathrm{ClO}_{2}+8 \mathrm{e}^{-}
\end{gathered}
$$

Table 1. Principal actions proposed explaining the deadliness of the electrochemical disinfection [19].

\begin{tabular}{cl}
\hline \multicolumn{1}{c}{ Electrochemical Disinfection Tools } \\
\hline Oxidants & \multicolumn{1}{c}{ Electric Field } \\
\hline Oxidative stress and cell loss of life. & $\begin{array}{l}\text { 1) Irreversible permeabilization of cell membranes. } \\
\text { 2) Electrochemical oxidation of vital cellular constituents. } \\
\text { 3) Electrosorption of negatively charged } E \text {. coli cells to the } \\
\text { anode surface + direct electron transfer reaction. }\end{array}$ \\
\hline
\end{tabular}


Table 2. EC mechanisms using $\mathrm{Fe}(\mathrm{pH} \mathrm{2,} 7$ and 12) and $\mathrm{Al}(\mathrm{pH} \mathrm{7)}$ electrodes [63] [64] [65] [66].

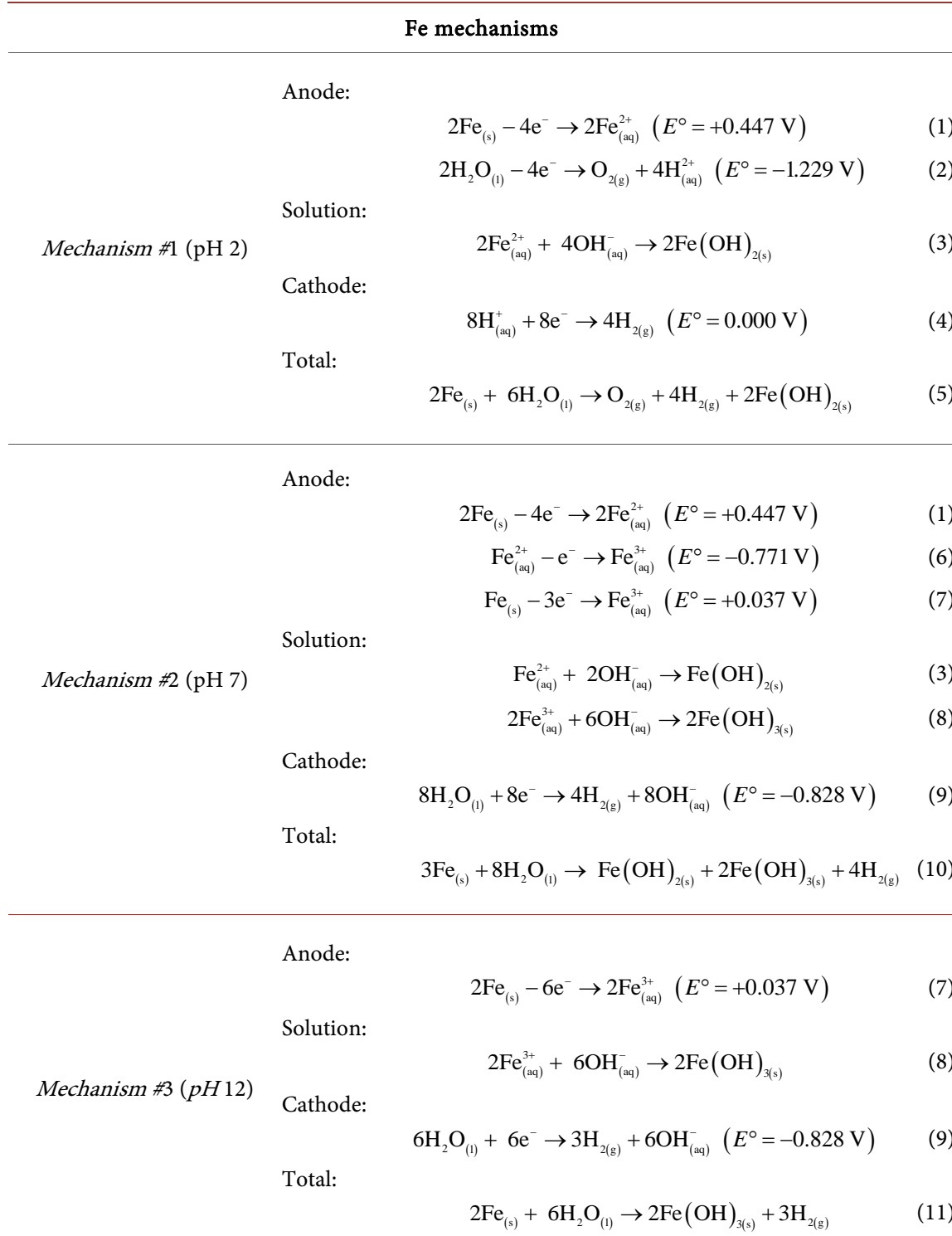

\section{Al mechanism}

Anode:

$$
\begin{gathered}
\mathrm{Al}_{(\mathrm{s})}-3 \mathrm{e}^{-} \rightarrow \mathrm{Ale}_{(\mathrm{aq})}^{3+}\left(E^{\circ}=+1.66 \mathrm{~V}\right) \\
2 \mathrm{H}_{2} \mathrm{O}_{(\mathrm{l})}-4 \mathrm{e}^{-} \rightarrow \mathrm{O}_{2(\mathrm{~g})}+4 \mathrm{H}_{(\mathrm{aq})}^{+}\left(E^{\circ}=-1.229 \mathrm{~V}\right)
\end{gathered}
$$

Solution:

Mechanism ( $p H 7)$

$$
\begin{gathered}
\mathrm{Al}_{(\text {aq) }}^{3+}+3 \mathrm{OH}_{(\text {aq) }}^{-} \rightarrow \mathrm{Al}(\mathrm{OH})_{3(\mathrm{~s})} \\
\mathrm{Al}(\mathrm{OH})_{4(\text { aq })}^{-} \rightarrow \mathrm{OH}_{(\text {aq) }}^{-}+\mathrm{Al}(\mathrm{OH})_{3(\mathrm{~s})}
\end{gathered}
$$

Cathode:

$$
\begin{gathered}
4 \mathrm{H}_{2} \mathrm{O}_{(\mathrm{l})}+4 \mathrm{e}^{-} \rightarrow 2 \mathrm{H}_{2(\mathrm{~g})}+4 \mathrm{OH}_{(\mathrm{aq})}^{-}\left(E^{\circ}=-0.828 \mathrm{~V}\right) \\
\mathrm{Al}_{(\mathrm{s})}+4 \mathrm{OH}_{(\mathrm{aq})}^{-}-3 \mathrm{e}^{-} \rightarrow \mathrm{Al}(\mathrm{OH})_{4(\mathrm{aq})}^{-}
\end{gathered}
$$

Total:

$$
2 \mathrm{Al}_{(\mathrm{s})}+8 \mathrm{H}_{2} \mathrm{O}_{(\mathrm{l})} \rightarrow 5 \mathrm{H}_{2(\mathrm{~g})}+2 \mathrm{Al}(\mathrm{OH})_{3(\mathrm{~s})}+\mathrm{O}_{2(\mathrm{~g})}
$$


Such chemicals may harm the membrane of the cell that leads to killing microbes.

\section{Electrocoagulation Employing Baffle-Plates Electrodes for Eliminating Escherichia coli}

Hashim et al. [1] suggested a novel EC device, which employs the notions of baffle-plates, for eliminating $E$. coli from wastewater (Figure 1). Such aluminum-based EC setup employs perforated baffle-plates electrodes to mix water, which decreases the necessity of mechanical or magnetic mixers that need additional power to run (Figure 2). They handled wastewater samples carrying $E$. coli, taking into account the impacts of treatment time (TT), inter-electrode distance (IED), and current density (CD). Their findings proved that the device reduces as high as $96 \%$ of the $E$. coli during $20 \mathrm{~min}$ of electrolysis at IED of 0.5 $\mathrm{cm}$, and $\mathrm{CD}$ of $1.5 \mathrm{~mA} / \mathrm{cm}^{2}$. Further, the working price of the suggested setup is $0.11 \mathrm{US} \$ / \mathrm{m}^{3}$ (for $E$. coli elimination), which is less than working price of conventional devices. They noted that the influence of the investigated factors on $E$. coli elimination pursued the order: TT $>$ CD $>$ IED.

\section{Ultrasonication of Electrocoagulation Reactor for Killing Escherichia coli}

Once again Hashim et al. [68] proposed a fresh hybrid ultrasonic-EC device to demobilize $E$. coli in water. The novel hybrid setup is composed of an ultrasonic bath fitted with four perforated aluminum electrodes. Such perforated electrodes are conceived to work as baffle-plates to improve the water-mixing phenomena (Figure 3). As mentioned in the previous Section, such metallic plates avoid the necessity of external mixing devices. At first, they regulated the capacity of the EC to demobilize E. coli for electrolyzing time, electrodes spacing and current density. The ultrasonic field was subsequently implemented through varying

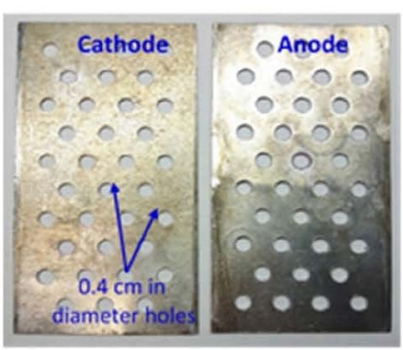

(A)

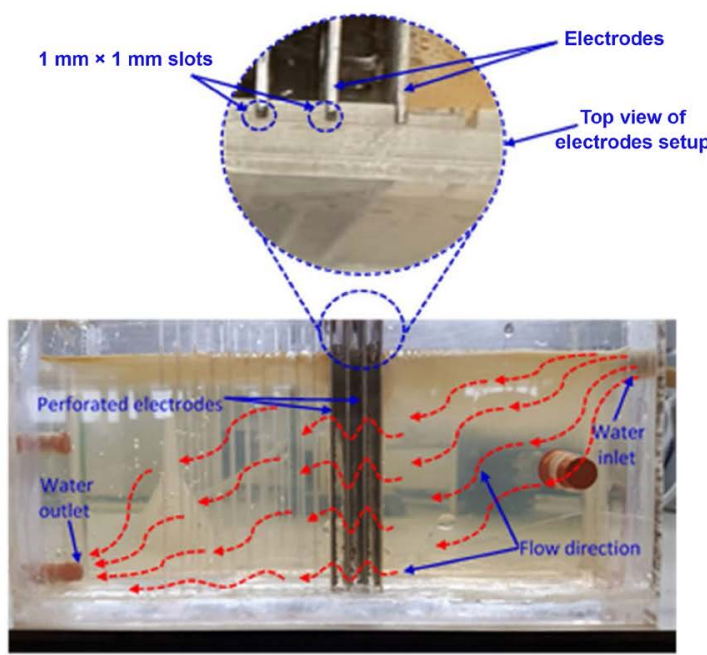

(B)

Figure 1. (A) Electrodes, (B) baffle-plates aluminum-based EC reactor [1]. 

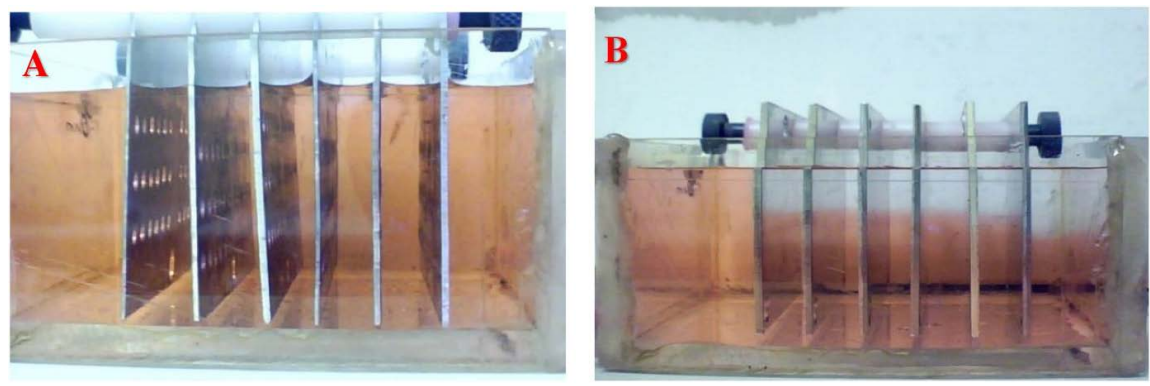

Figure 2. Mixing efficiency of (A) baffle-plates aluminum-based EC reactor, (B) A traditional EC reactor [1].

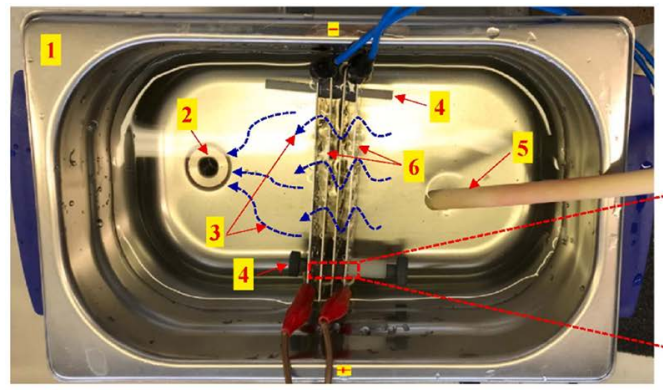

1) Ultrasonic bath

2) Water outlet

3) Flow direction

4) Insulation

5) Water inlet

6) Perforated electrodes

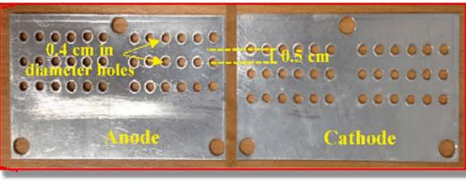

The perforated electrodes

Figure 3. The ultrasonic-EC reactor [68].

time periods, over the period of the electrolyzing method. They proved that the new ultrasonic-EC device killed $100 \%$ of the $E$. coli in $11 \mathrm{~min}$ of electrolysis at electrodes spacing of $5 \mathrm{~mm}$, current density of $1.5 \mathrm{~mA} / \mathrm{cm}^{2}$, and an operation cost of 0.212 US $\$ / \mathrm{m}^{3}$.

\section{EC Next Tendencies}

As mentioned previously, EC stays a viable solution for classical coagulation, through which the coagulant is furnished via solubilizing sacrificial electrodes upon an applied electric field [34] [69]. The easiness of the technology and the side phenomena involving the generation of gas bubbles are the major advantages. Even if the laboratory design of an EC cell is extremely easy, its scale-up is not as simple, especially for large water treatment plants. It is not frequently ready to employ tank cells with sheets of $\mathrm{Fe}$ and $\mathrm{Al}$, and there is a necessity to employ cheap materials as sacrificial electrodes. Employing low-quality Fe or Al may enable bipolar electrode configurations to be used. Integrating EC with free radical assisted processes (e.g., electrooxidation), magnetic field [66] [70] [71] [72] [73] [74] and/or ultrasonic field remains an encouraging method to promote its implantation at full scale [64] [69].

During EC process, there are two induced phenomena: electrophoresis and electroflotation [75]; separately, they are well known in electrochemistry's applications and well developed technically and mathematically [76]. How important are these inherent phenomena in EC process efficiency, particularly in removing pathogens deserves more focus [77]. 
The superior performance of ferrate (VI) has been demonstrated through several studies [78]. The practical aspect of many of them was to demonstrate the feasibility of the online generation and application of ferrate (VI) for sewage treatment [79] [80] [81], which could lead to the implementation of ferrate (VI) technology in water and wastewater treatment [82]-[93] practice. Electrochemical generation of ferrate (VI) is similar to EC process. Consequently, merging ferrate (VI) produced electrochemically with EC [94] [95] [96] [97] constitutes an interesting field of research [98] [99].

Membrane processes should be considered as safe barriers towards DBPs and hydroxyl radicals' (probably generated during EC process [64]) removal [100][105].

\section{Conclusions}

From this work, the following conclusions can be drawn:

1) A recent study proved that baffle-plates aluminum-based EC reactor has the potential to kill $96 \%$ of $E$. coli from synthetic wastewater, which is identical to the mentioned performances in the literature [1]. Further, the baffle-plates aluminum-based EC reactor consumes less energy than conventional units perform since it does not necessitate external water mixing devices. E. coli reduction is more considerable at high current densities and long residence time. Perversely, eliminating $E$. coli is reversely proportional to the distance separating the electrodes. The contact period is the most important parameter in killing $E$. coli; however, the gap among the anode and the cathode has the lowest effect.

2) A fresh hybrid ultrasonic-EC device was presented to kill E. coli existing in water [68]. The setup may be a helpful and cost-efficient choice to classical methods for disinfecting water. The survivability of $E$. coli considerably diminishes with an elevation of the electrolyzing period, ultrasonication time or applied current density. As a perspective, studying the pathways of E. coli demobilization employing the combined EC with ultrasonication merits more attention.

3) In the EC process, the microbes may be demobilized thanks to the direct adsorption on the surface of the anode pursued by electron transfer, and physical elimination through floating pathogens with formed hydrogen gas and/or precipitating with the produced flocs. Integrating EC with free radical assisted processes (e.g., electrooxidation), magnetic field and/or ultrasonic field remains an encouraging method to promote its implantation at full scale. Membrane processes should be considered as safe barriers towards disinfection by-products and hydroxyl radicals.

\section{Conflicts of Interest}

The authors declare no conflicts of interest regarding the publication of this paper.

\section{References}

[1] Hashim, K.S., Kot, P., Zubaidi, S.L., Alwash, R., Al Khaddar, R., Shaw, A., 
Al-Jumeily, D. and Aljefery, M.H. (2020) Energy Efficient Electrocoagulation Using Baffle-Plates Electrodes for Efficient Escherichia coli Removal from Wastewater. Journal of Water Process Engineering, 33, Article ID: 101079. https://doi.org/10.1016/j.jwpe.2019.101079

[2] Ghernaout, D., Ghernaout, B. and Naceur, M.W. (2011) Embodying the Chemical Water Treatment in the Green Chemistry-A Review. Desalination, 271, 1-10. https://doi.org/10.1016/j.desal.2011.01.032

[3] Okoh, A.I., Odjadjare, E.E., Igbinosa, E.O. and Osode, A.N. (2007) Wastewater Treatment Plants as a Source of Microbial Pathogens in Receiving Watersheds. African Journal of Biotechnology, 6, 2932-2944. https://doi.org/10.5897/AJB2007.000-2462

[4] Al-Saati, N.H., Hussein, T.K., Abbas, M.H., Hashim, K., Al-Saati, Z.N., Kot, P., Sadique, M., Aljefery, M.H. and Carnacina, I. (2019) Statistical Modelling of Turbidity Removal Applied to Non-Toxic Natural Coagulants in Water Treatment: A Case Study. Desalination and Water Treatment, 150, 406-412. https://doi.org/10.5004/dwt.2019.23871

[5] Lombardi, G., Stefani, G., Paci, A., Becagli, C., Miliacca, M., Gastaldi, M., Giannetti, B. and Almeida, C. (2019) The Sustainability of the Italian Water Sector: An Empirical Analysis by DEA. Journal of Cleaner Production, 227, 1035-1043. https://doi.org/10.1016/j.jclepro.2019.04.283

[6] Dhadge, V.L., Medhi, C.R., Changmai, M. and Purkait, M.K. (2018) House Hold Unit for the Treatment of Fluoride, Iron, Arsenic and Microorganism Contaminated Drinking Water. Chemosphere, 199, 728-736. https://doi.org/10.1016/j.chemosphere.2018.02.087

[7] Hashim, K.S., Al-Saati, N.H., Hussein, A.H. and Al-Saati, Z.N. (2018) An Investigation into the Level of Heavy Metals Leaching from Canal-Dreged Sediment: A Case Study Metals Leaching from Dreged Sediment. 1st International Conference on Materials Engineering \& Science, Istanbul, 12-22.

[8] Ramirez-Castillo, F.Y., Loera-Muro, A., Jacques, M., Garneau, P., Avelar-Gonzalez, F.J., Harel, J. and Guerrero-Barrera, A.L. (2015) Waterborne Pathogens: Detection Methods and Challenges. Pathogens, 4, 307-334. https://doi.org/10.3390/pathogens4020307

[9] Alattabi, A.W., Harris, C.B., Alkhaddar, R.M., Hashim, K.S., Ortoneda-Pedrola, M. and Phipps, D. (2017) Improving Sludge Settle Ability by Introducing an Innovative, Two-Stage Settling Sequencing Batch Reactor. Journal of Water Process Engineering, 20, 207-216. https://doi.org/10.1016/j.jwpe.2017.11.004

[10] Baran, W., Adamek, E., Jajko, M. and Sobczak, A. (2018) Removal of Veterinary Antibiotics from Wastewater by Electrocoagulation. Chemosphere, 194, 381-389. https://doi.org/10.1016/j.chemosphere.2017.11.165

[11] Ghernaout, D. (2017) Environmental Principles in the Holy Koran and the Sayings of the Prophet Muhammad. American Journal of Environmental Protection, 6, 75-79. https://doi.org/10.11648/j.ajep.20170603.13

[12] WHO (2015) Water-Related Diseases. World Health Organization. http://www.who.int/water sanitation health/diseases-risks/diseases/diarrhoea/en

[13] Ghernaout, D. and Elboughdiri, N. (2020) Is Not It Time to Stop Using Chlorine for Treating Water? Open Access Library Journal, 7, e6007.

[14] Ghernaout, D., Moulay, S., Ait Messaoudene, N., Aichouni, M., Naceur, M.W. and Boucherit, A. (2014) Coagulation and Chlorination of NOM and Algae in Water Treatment: A Review. International Journal of Environmental Monitoring and 
Analysis, 2, 23-34. https://doi.org/10.11648/j.ijema.s.2014020601.14

[15] Ghernaout, D. (2017) Water Treatment Chlorination: An Updated Mechanistic Insight Review. Chemistry Research Journal, 2, 125-138.

[16] Ghernaout, D., Alghamdi, A., Aichouni, M. and Touahmia, M. (2018) The Lethal Water Tri-Therapy: Chlorine, Alum, and Polyelectrolyte. World Journal of Applied Chemistry, 3, 65-71. https://doi.org/10.11648/j.wjac.20180302.14

[17] Ghernaout, D. and Ghernaout, B. (2010) From Chemical Disinfection to Electrodisinfection: The Obligatory Itinerary? Desalination and Water Treatment, 16, 156-175. https://doi.org/10.5004/dwt.2010.1085

[18] Boucherit, A., Moulay, S., Ghernaout, D., Al-Ghonamy, A.I., Ghernaout, B., Naceur, M.W., Ait Messaoudene, N., Aichouni, M., Mahjoubi, A.A. and Elboughdiri, N.A. (2015) New Trends in Disinfection By-Products Formation upon Water Treatment. Journal of Research \& Developments in Chemistry, 2015, Article ID: 628833. https://doi.org/10.5171/2015.628833

[19] Ghernaout, D. (2017) Microorganisms' Electrochemical Disinfection Phenomena. EC Microbiology, 9, 160-169.

[20] Ghernaout, D. (2018) Disinfection and DBPs Removal in Drinking Water Treatment: A Perspective for a Green Technology. International Journal of Advanced and Applied Sciences, 5, 108-117. https://doi.org/10.21833/ijaas.2018.02.018

[21] Ghernaout, D., Touahmia, M. and Aichouni, M. (2019) Disinfecting Water: Electrocoagulation as an Efficient Process. Applied Engineering, 3, 1-12.

[22] Ghernaout, D., Aichouni, M. and Touahmia, M. (2019) Mechanistic Insight into Disinfection by Electrocoagulation-A Review. Desalination and Water Treatment, 141, 68-81. https://doi.org/10.5004/dwt.2019.23457

[23] Ghernaout, D., Alghamdi, A. and Ghernaout, B. (2019) Microorganisms' Killing: Chemical Disinfection vs. Electrodisinfection. Applied Engineering, 3, 13-19.

[24] Ghernaout, D. (2019) Greening Electrocoagulation Process for Disinfecting Water. Applied Engineering, 3, 27-31.

[25] Bidhendi, G.N., Hoveidi, H., Jafari, H., Karbassi, A. and Nasrabadi, T. (2006) Application of Ozonation in Drinking Water Disinfection Based on an Environmental Management Strategy Approach Using SWOT Method. Iranian Journal of Environmental Health Science \& Engineering, 3, 23-30.

[26] Castro-Rios, K., Taborda-Ocampo, G. and Torres-Palma, R.A. (2014) Experimental Design to Measure Escherichia coli Removal in Water through Electrocoagulation. International Journal of Electrochemical Science, 9, 610-617.

[27] Ghernaout, D. (2014) The Hydrophilic/Hydrophobic Ratio vs. Dissolved Organics Removal by Coagulation: A Review. Journal of King Saud University-Science, 26, 169-180. https://doi.org/10.1016/j.jksus.2013.09.005

[28] Ghernaout, D., Al-Ghonamy, A.I., Boucherit, A., Ghernaout, B., Naceur, M.W., Ait Messaoudene, N., Aichouni, M., Mahjoubi, A.A. and Elboughdiri, N.A. (2015) Brownian Motion and Coagulation Process. American Journal of Environmental Protection, 4, 1-15. https://doi.org/10.11648/j.ajeps.s.2015040501.11

[29] Ghernaout, D., Al-Ghonamy, A.I., Naceur, M.W., Boucherit, A., Messaoudene, N.A., Aichouni, M., Mahjoubi, A.A. and Elboughdiri, N.A. (2015) Controlling Coagulation Process: From Zeta Potential to Streaming Potential. American Journal of Environmental Protection, 4, 16-27. https://doi.org/10.11648/j.ajeps.s.2015040501.12

[30] Ghernaout, D. and Boucherit, A. (2015) Review of Coagulation's Rapid Mixing for 
NOM Removal. Journal of Research \& Developments in Chemistry, 2015, Article ID: 926518. https://doi.org/10.5171/2015.926518

[31] Ghernaout, D., Badis, A., Braikia, G., Matâam, N., Fekhar, M., Ghernaout, B. and Boucherit, A. (2017) Enhanced Coagulation for Algae Removal in a Typical Algeria Water Treatment Plant. Environmental Engineering and Management Journal, 16, 2303-2315. https://doi.org/10.30638/eemj.2017.238

[32] Ghernaout, D. (2017) Entropy in the Brownian Motion (BM) and Coagulation Background. Colloid and Surface Science, 2, 143-161.

[33] Collivignarelli, M.C., Abbà, A., Benigna, I., Sorlini, S. and Torretta, V. (2017) Overview of the Main Disinfection Processes for Wastewater and Drinking Water Treatment Plants. Sustainability, 10, 86. https://doi.org/10.3390/su10010086

[34] Ghernaout, D., Badis, A., Ghernaout, B. and Kellil, A. (2008) Application of Electrocoagulation in Escherichia coli Culture and Two Surface Waters. Desalination, 219, 118-125. https://doi.org/10.1016/j.desal.2007.05.010

[35] Zhou, J., Wang, T. and Xie, X. (2019) Rationally Designed Tubular Coaxial-Electrode Copper Ionization Cells (CECICs) Harnessing Non-Uniform Electric Field for Efficient Water Disinfection. Environment International, 128, 30-36.

https://doi.org/10.1016/j.envint.2019.03.072

[36] Moreno-Andrés, J., Ambauen, N., Vadstein, O., Hallé, C., Acevedo-Merino, A., Nebot, E. and Meyn, T. (2018) Inactivation of Marine Heterotrophic Bacteria in Ballast Water by an Electrochemical Advanced Oxidation Process. Water Research, 140, 377-386. https://doi.org/10.1016/j.watres.2018.04.061

[37] Ghernaout, D., Alghamdi, A., Touahmia, M., Aichouni, M. and Ait Messaoudene, N. (2018) Nanotechnology Phenomena in the Light of the Solar Energy. Journal of Energy, Environmental \& Chemical Engineering, 3, 1-8. https://doi.org/10.11648/j.jeece.20180301.11

[38] Hernández, M.C., Barletta, L., Dogliotti, M., Russo, N., Fino, D. and Spinelli, P. (2012) Heavy Metal Removal by Means of Electrocoagulation Using Aluminum Electrodes for Drinking Water Purification. Journal of Applied Electrochemistry, 42, 809-817. https://doi.org/10.1007/s10800-012-0455-8

[39] Betancor-Abreu, A., Mena, V., González, S., Delgado, S., Souto, R. and Santana, J. (2019) Design and Optimization of an Electrocoagulation Reactor for Fluoride Remediation in Underground Water Sources for Human Consumption. Journal of Water Process Engineering, 31, Article ID: 100865. https://doi.org/10.1016/j.jwpe.2019.100865

[40] Guvenc, S.Y., Dincer, K. and Varank, G. (2019) Performance of Electrocoagulation and Electro-Fenton Processes for Treatment of Nanofiltration Concentrate of Biologically Stabilized Landfill Leachate. Journal of Water Process Engineering, 31, Article ID: 100863. https://doi.org/10.1016/j.jwpe.2019.100863

[41] Ghernaout, D., Irki, S. and Boucherit, A. (2014) Removal of $\mathrm{Cu}^{2+}$ and $\mathrm{Cd}^{2+}$, and Humic Acid and Phenol by Electrocoagulation Using Iron Electrodes. Desalination and Water Treatment, 52, 3256-3270. https://doi.org/10.1080/19443994.2013.852484

[42] Ghernaout, D., Al-Ghonamy, A.I., Naceur, M.W., Ait Messaoudene, N. and Aichouni, M. (2014) Influence of Operating Parameters on Electrocoagulation of C.I. Disperse Yellow 3. Journal of Electrochemical Science and Engineering, 4, 271-283. https://doi.org/10.5599/jese.2014.0065

[43] Ghernaout, D., Al-Ghonamy, A.I., Irki, S., Grini, A., Naceur, M.W., Ait Messaoudene, N. and Aichouni, M. (2014) Decolourization of Bromophenol Blue by Elec- 
trocoagulation Process. Trends in Chemical Engineering, 15, 29-39.

[44] Ghernaout, D., Al-Ghonamy, A.I., Ait Messaoudene, N., Aichouni, M., Naceur, M.W., Benchelighem, F.Z. and Boucherit, A. (2015) Electrocoagulation of Direct Brown 2 (DB) and BF Cibacete Blue (CB) Using Aluminum Electrodes. Separation Science and Technology, 50, 1413-1420. https://doi.org/10.1080/01496395.2014.982763

[45] Ghernaout, D. and Ghernaout, B. (2011) On the Controversial Effect of Sodium Sulphate as Supporting Electrolyte on Electrocoagulation Process: A Review. Desalination and Water Treatment, 27, 243-254. https://doi.org/10.5004/dwt.2011.1983

[46] Hashim, K.S., Shaw, A., Al Khaddar, R., Pedrola, M.O. and Phipps, D. (2017) Energy Efficient Electrocoagulation Using a New Flow Column Reactor to Remove Nitrate from Drinking Water-Experimental, Statistical, and Economic Approach. Journal of Environmental Management, 196, 224-233.

https://doi.org/10.1016/j.jenvman.2017.03.017

[47] Myllymäki, P., Lahti, R., Romar, H. and Lassi, U. (2018) Removal of Total Organic Carbon from Peat Solution by Hybrid Method-Electrocoagulation Combined with Adsorption. Journal of Water Process Engineering, 24, 56-62.

https://doi.org/10.1016/j.jwpe.2018.05.008

[48] Doggaz, A., Attoura, A., Mostefa, M.L.P., Côme, K., Tlili, M. and Lapicque, F. (2018) Removal of Heavy Metals by Electrocoagulation from Hydrogenocarbonate-Containing Waters: Compared Cases of Divalent Iron and Zinc Cations. Journal of Water Process Engineering, 29, Article ID: 100796. https://doi.org/10.1016/j.jwpe.2019.100796

[49] Barrera-Diaz, C., Martinez-Barrera, G., Gencel, O., Bernal-Martinez, L.A. and Brostow, W. (2011) Processed Wastewater Sludge for Improvement of Mechanical Properties of Concretes. Journal of Hazardous Materials, 192, 108-115. https://doi.org/10.1016/j.jhazmat.2011.04.103

[50] Alattabi, A.W., Harris, C., Alkhaddar, R., Alzeyadi, A. and Hashim, K. (2017) Treatment of Residential Complexes' Wastewater Using Environmentally Friendly Technology. Procedia Engineering, 196, 792-799. https://doi.org/10.1016/j.proeng.2017.08.009

[51] Ghernaout, D., Ghernaout, B. and Kellil, A. (2009) Natural Organic Matter Removal and Enhanced Coagulation as a Link between Coagulation and Electrocoagulation. Desalination and Water Treatment, 2, 203-222.

https://doi.org/10.5004/dwt.2009.116

[52] Saiba, A., Kourdali, S., Ghernaout, B. and Ghernaout, D. (2010) In Desalination, from 1987 to 2009, the Birth of a New Seawater Pretreatment Process: Electrocoagulation-An Overview. Desalination and Water Treatment, 16, 201-217. https://doi.org/10.5004/dwt.2010.1094

[53] Ghernaout, D. (2019) Electrocoagulation and Electrooxidation for Disinfecting Water: New Breakthroughs and Implied Mechanisms. Applied Engineering, 3, 125-133.

[54] Ghernaout, D. and Elboughdiri, N. (2019) Electrocoagulation Process Intensification for Disinfecting Water: A Review. Applied Engineering, 3, 140-147.

[55] Ghernaout, D. and Elboughdiri, N. (2019) Iron Electrocoagulation Process for Disinfecting Water: A Review. Applied Engineering, 3, 154-158.

[56] Un, U.T., Koparal, A.S. and Bakir Ogutveren, U. (2013) Fluoride Removal from Water and Wastewater with a Batch Cylindrical Electrode Using Electrocoagulation. Chemical Engineering Journal, 223, 110-115. 
https://doi.org/10.1016/j.cej.2013.02.126

[57] Ghernaout, D. (2019) Disinfection via Electrocoagulation Process: Implied Mechanisms and Future Tendencies. EC Microbiology, 15, 79-90.

[58] Ghernaout, D., Ghernaout, B. and Boucherit, A. (2008) Effect of pH on Electrocoagulation of Bentonite Suspensions in Batch Using Iron Electrodes. Journal of Dispersion Science and Technology, 29, 1272-1275. https://doi.org/10.1080/01932690701857483

[59] Pulido, M.E. (2005) Evaluation of an Electro-Disinfection Technology as an Alternative to Chlorination of Municipal Wastewater Effluents. PhD Thesis, Engineering and Applied Science, University of New Orleans, New Orleans.

[60] Gusmão, I.C.C.P., Moraes, P.B. and Bidoia, E.D. (2010) Studies on the Electrochemical Disinfection of Water Containing Escherichia coli Using a Dimensionally Stable Anode. Brazilian Archives of Biology and Technology, 53, 1235-1244.

https://doi.org/10.1590/S1516-89132010000500029

[61] Ndjomgoue-Yossa, A., Nanseu-Njiki, C., Kengne, I. and Ngameni, E. (2015) Effect of Electrode Material and Supporting Electrolyte on the Treatment of Water Containing Escherichia coli by Electrocoagulation. International Journal of Environmental Science and Technology, 12, 2103-2110. https://doi.org/10.1007/s13762-014-0609-9

[62] Ghernaout, D. (2017) The Holy Koran Revelation: Iron Is a "Sent Down" Metal. American Journal of Environmental Protection, 6, 101-104.

https://doi.org/10.11648/j.ajep.20170604.14

[63] Ghernaout, D., Ghernaout, B., Boucherit, A., Naceur, M.W., Khelifa, A. and Kellil, A. (2009) Study on Mechanism of Electrocoagulation with Iron Electrodes in Idealised Conditions and Electrocoagulation of Humic Acids Solution in Batch Using Aluminium Electrodes. Desalination and Water Treatment, 8, 91-99.

https://doi.org/10.5004/dwt.2009.668

[64] Ghernaout, D. (2013) Advanced Oxidation Phenomena in Electrocoagulation Process: A Myth or a Reality? Desalination and Water Treatment, 51, 7536-7554. https://doi.org/10.1080/19443994.2013.792520

[65] Ghernaout, D., Alghamdi, A. and Ghernaout, B. (2019) Electrocoagulation Process: A Mechanistic Review at the Dawn of Its Modeling. Journal of Environmental Science and Allied Research, 2, 51-67. https://doi.org/10.29199/2637-7063/ESAR-201019

[66] Irki, S., Ghernaout, D. and Naceur, M.W. (2017) Decolourization of Methyl Orange (MO) by Electrocoagulation (EC) Using Iron Electrodes under a Magnetic Field (MF). Desalination and Water Treatment, 79, 368-377. https://doi.org/10.5004/dwt.2017.20797

[67] Ghernaout, D., Naceur, M.W. and Aouabed, A. (2011) On the Dependence of Chlorine By-Products Generated Species Formation of the Electrode Material and Applied Charge during Electrochemical Water Treatment. Desalination, 270, 9-22. https://doi.org/10.1016/j.desal.2011.01.010

[68] Hashim, B., et al. (2020) Escherichia coli Inactivation Using a Hybrid Ultrasonic-Electrocoagulation Reactor. Chemosphere, 247, Article ID: 125868. https://doi.org/10.1016/j.chemosphere.2020.125868

[69] Ghernaout, D. (2019) Virus Removal by Electrocoagulation and Electrooxidation: New Findings and Future Trends. Journal of Environmental Science and Allied Research, 2019, 85-90.

[70] Ghernaout, D., Mariche, A., Ghernaout, B. and Kellil, A. (2010) Electromagnetic 
Treatment-Bi-Electrocoagulation of Humic Acid in Continuous Mode Using Response Surface Method for Its Optimization and Application on Two Surface Waters. Desalination and Water Treatment, 22, 311-329. https://doi.org/10.5004/dwt.2010.1120

[71] Ghernaout, D. (2018) Magnetic Field Generation in the Water Treatment Perspectives: An Overview. International Journal of Advanced and Applied Sciences, 5, 193-203. https://doi.org/10.21833/ijaas.2018.01.025

[72] Irki, S., Ghernaout, D., Naceur, M.W., Alghamdi, A. and Aichouni, M. (2018) Decolorization of Methyl Orange (MO) by Electrocoagulation (EC) Using Iron Electrodes under a Magnetic Field (MF). II. Effect of Connection Mode. World Journal of Applied Chemistry, 3, 56-64. https://doi.org/10.11648/j.wjac.20180302.13

[73] Ghernaout, D. and Elboughdiri, N. (2020) Magnetic Field Application: An Underappreciated Outstanding Technology. Open Access Library Journal, 7, e6000.

[74] Ghernaout, D., Ghernaout, B., Saiba, A., Boucherit, A. and Kellil, A. (2009) Removal of Humic Acids by Continuous Electromagnetic Treatment Followed by Electrocoagulation in Batch Using Aluminium Electrodes. Desalination, 239, 295-308. https://doi.org/10.1016/j.desal.2008.04.001

[75] Ghernaout, D., Benblidia, C. and Khemici, F. (2015) Microalgae Removal from Ghrib Dam (Ain Defla, Algeria) Water by Electroflotation Using Stainless Steel Electrodes. Desalination and Water Treatment, 54, 3328-3337.

https://doi.org/10.1080/19443994.2014.907749

[76] Ghernaout, D., Naceur, M.W. and Ghernaout, B. (2011) A Review of Electrocoagulation as a Promising Coagulation Process for Improved Organic and Inorganic Matters Removal by Electrophoresis and Electroflotation. Desalination and Water Treatment, 28, 287-320. https://doi.org/10.5004/dwt.2011.1493

[77] Belhout, D., Ghernaout, D., Djezzar-Douakh, S. and Kellil, A. (2010) Electrocoagulation of a Raw Water of Ghrib Dam (Algeria) in Batch Using Iron Electrodes. Desalination and Water Treatment, 16, 1-9. https://doi.org/10.5004/dwt.2010.1081

[78] Ghernaout, D. and Naceur, M.W. (2011) Ferrate(VI): In Situ Generation and Water Treatment-A Review. Desalination and Water Treatment, 30, 319-332. https://doi.org/10.5004/dwt.2011.2217

[79] Ghernaout, D. and Elboughdiri, N. (2019) Upgrading Wastewater Treatment Plant to Obtain Drinking Water. Open Access Library Journal, 6, e5959. https://doi.org/10.4236/oalib.1105959

[80] Ghernaout, D., Elboughdiri, N. and Alghamdi, A. (2019) Direct Potable Reuse: The Singapore NEWater Project as a Role Model. Open Access Library Journal, 6, e5980. https://doi.org/10.4236/oalib.1105980

[81] Ghernaout, D. and Elboughdiri, N. (2019) Water Reuse: Emerging Contaminants Elimination-Progress and Trends. Open Access Library Journal, 6, e5981.

[82] Ghernaout, D. (2017) Water Reuse (WR): The Ultimate and Vital Solution for Water Supply Issues. International Journal of Sustainable Development Research, 3, 36-46. https://doi.org/10.11648/j.ijsdr.20170304.12

[83] Ghernaout, D. and Elboughdiri, N. (2020) Strategies for Reducing Disinfection By-Products Formation during Electrocoagulation. Open Access Library Journal, 7, e6076. https://doi.org/10.4236/oalib.1106076

[84] Ghernaout, D. (2018) Increasing Trends towards Drinking Water Reclamation from Treated Wastewater. World Journal of Applied Chemistry, 3, 1-9. https://doi.org/10.11648/j.wjac.20180301.11 
[85] Ghernaout, D. and Ghernaout, B. (2012) On the Concept of the Future Drinking Water Treatment Plant: Algae Harvesting from the Algal Biomass for Biodiesel Production-A Review. Desalination and Water Treatment, 49, 1-18. https://doi.org/10.1080/19443994.2012.708191

[86] Ghernaout, D. (2013) The Best Available Technology of Water/Wastewater Treatment and Seawater Desalination: Simulation of the Open Sky Seawater Distillation. Green and Sustainable Chemistry, 3, 68-88. https://doi.org/10.4236/gsc.2013.32012

[87] Ghernaout, D., Alshammari, Y. and Alghamdi, A. (2018) Improving Energetically Operational Procedures in Wastewater Treatment Plants. International Journal of Advanced and Applied Sciences, 5, 64-72. https://doi.org/10.21833/ijaas.2018.09.010

[88] Al Arni, S., Amous, J. and Ghernaout, D. (2019) On the Perspective of Applying of a New Method for Wastewater Treatment Technology: Modification of the Third Traditional Stage with Two Units, One by Cultivating Microalgae and Another by Solar Vaporization. International Journal of Environmental Sciences \& Natural Resources, 16, Article ID: 555934. https://doi.org/10.19080/IJESNR.2019.16.555934

[89] Alshammari, Y., Ghernaout, D., Aichouni, M. and Touahmia, M. (2018) Improving Operational Procedures in Riyadh's (Saudi Arabia) Water Treatment Plants Using Quality Tools. Applied Engineering, 2, 60-71.

[90] Ghernaout, D. (2019) Aeration Process for Removing Radon from Drinking Water: A Review. Applied Engineering, 3, 32-45.

[91] Ghernaout, D. (2019) Reviviscence of Biological Wastewater Treatment: A Review. Applied Engineering, 3, 46-55.

[92] Ghernaout, D., Elboughdiri, N. and Al Arni, S. (2019) Water Reuse (WR): Dares, Restrictions, and Trends. Applied Engineering, 3, 159-170.

[93] Ghernaout, D., Elboughdiri, N. and Ghareba, S. (2019) Drinking Water Reuse: One-Step Closer to Overpassing the "Yuck Factor". Open Access Library Journal, 6, e5895. https://doi.org/10.4236/oalib.1105895

[94] Ghernaout, D. (2018) Electrocoagulation Process: Achievements and Green Perspectives. Colloid and Surface Science, 3, 1-5. https://doi.org/10.11648/j.css.20180301.11

[95] Irki, S., Ghernaout, D., Naceur, M.W., Alghamdi, A. and Aichouni, M. (2018) Decolorizing Methyl Orange by Fe-Electrocoagulation Process-A Mechanistic Insight. International Journal of Environmental Chemistry, 2, 18-28. https://doi.org/10.11648/j.ijec.20180201.14

[96] Ghernaout, D. (2019) Electrocoagulation Process for Microalgal Biotechnology-A Review. Applied Engineering, 3, 85-94.

[97] Ghernaout, D. and Elboughdiri, N. (2020) Electrochemical Technology for Wastewater Treatment: Dares and Trends. Open Access Library Journal, 7, e6020.

[98] Ghernaout, D. and Elboughdiri, N. (2019) Mechanistic Insight into Disinfection Using Ferrate(VI). Open Access Library Journal, 6, e5946.

[99] Ghernaout, D. and Elboughdiri, N. (2019) Water Disinfection: Ferrate(VI) as the Greenest Chemical-A Review. Applied Engineering, 3, 171-180.

[100] Ghernaout, D. and El-Wakil, A. (2017) Requiring Reverse Osmosis Membranes Modifications-An Overview. American Journal of Chemical Engineering, 5, 81-88. https://doi.org/10.11648/j.ajche.20170504.15

[101] Ghernaout, D. (2017) Reverse Osmosis Process Membranes Modeling-A Historical Overview. Journal of Civil, Construction and Environmental Engineering, 2, 112-122. 
[102] Ghernaout, D., El-Wakil, A., Alghamdi, A., Elboughdiri, N. and Mahjoubi, A. (2018) Membrane Post-Synthesis Modifications and How It Came About. International Journal of Advanced and Applied Sciences, 5, 60-64. https://doi.org/10.21833/ijaas.2018.02.010

[103] Ghernaout, D., Alshammari, Y., Alghamdi, A., Aichouni, M., Touahmia, M. and Ait Messaoudene, N. (2018) Water Reuse: Extenuating Membrane Fouling in Membrane Processes. International Journal of Environmental Chemistry, 2, 1-12. https://doi.org/10.11648/j.ajche.20180602.12

[104] Ghernaout, D. (2019) Brine Recycling: Towards Membrane Processes as the Best Available Technology. Applied Engineering, 3, 71-84.

[105] Ait Messaoudene, N., Naceur, M.W., Ghernaout, D., Alghamdi, A. and Aichouni, M. (2018) On the Validation Perspectives of the Proposed Novel Dimensionless Fouling Index. International Journal of Advanced and Applied Sciences, 5, 116-122. https://doi.org/10.21833/ijaas.2018.07.014 